\title{
PERANCANGAN SISTEM INFORMASI DATABASE PEMBELIAN DAN PENJUALAN PRODUK PADA SHAVIRA PANCAKE BANDA ACEH
}

\author{
Furqaan Putra ${ }^{1}$, Rudy Fachruddin ${ }^{* 2}$ \\ ${ }^{1,2}$ Program Studi Akuntansi Fakultas Ekonomi dan Bisnis Universitas Syiah Kuala \\ e-mail: furqansyf@gmail.com ${ }^{1}$, rudy_ipah@unsyiah.ac.id ${ }^{2}$
}

\section{* Corresponding Author}

\begin{abstract}
Abstrak
Purchase and sales are things which often heard in a company. The use of manual recording results in a number of problems in the company. Seeing the results of purchases, sales and transaction data manually would take a long time. This study aims to design a database of purchases and sales information systems to help employees manage purchase and sale transactions easier, therefore reducing errors and speed up the proccess of transaction calculations. The system designed in this study uses Microsoft Access. This study uses descriptive qualitative method, data collection techniques was done by conducting interviews, observations, and literature studies carried out directly with the owner of the company. This study produces an application system that would ease future corporate activities.
\end{abstract}

Keywords: Information System, Accounting Information System, Purchase, Sale dan Microsoft Access

\section{Pendahuluan}

Perkembangan teknologi yang saat ini perkembangannya sudah mempengaruhi kehidupan masyarakat dan juga berimbas pada bidang ekonomi dan bisnis yang membuat perusahaan harus mengelola perusahaannya dan harus melakukan penyesuaian diri dengan perkembangan teknologi yang terjadi saat ini. Sengitnya persaingan dalam kegiatan bisnis yang semakin keras mengharuskan perusahaan untuk berlomba-lomba dalam menghasilkan ide dan berinovasi guna memanfaatkan perkembangan teknologi informasi agar perusahaan mampu menjawab permintaan konsumen dengan tujuan menghasilkan profit dan memberikan pelayanan yang baik untuk konsumen serta menjamin kesejahteraan karyawan perusahaan.

Adanya perkembangan teknologi yang sangat pesat, membuat perusahaan harus jeli dalam melihat potensi bisnis yang melibatkan unsur teknologi informasi didalamnya. Potensi yang dihasilkan akibat adanya perkembangan teknologi informasi sangat luas sehingga membuat persaingan bisnis menjadi semakin ketat. Apabila suatu perusahaan tidak memanfaatkan potensi tersebut, perusahaan tersebut berpotensi tertinggal dengan perusahaan yang menghasilkan ide dan berinovasi dengan unsur teknologi informasi.
Saat ini pemanfaatan teknologi informasi sangat banyak diterapkan oleh perusahaan maupun organisasi, salah satunya sistem informasi. Sistem informasi merupakan suatu sistem di dalam organisasi yang mempertemukan kebutuhan pengolahan transaksi harian, mendukung operasi, bersifat manajerial dan kegiatan strategi dari suatu organisasi dan menyediakan pihak luar dengan laporan-laporan yang dibutuhkan (Bastian, Prasetyo, \& Kurniati, 2017). Dukungan sistem informasi yang baik akan menghasilkan keunggulan yang mompetitif bagi perusahaan, sehingga mampu bersaing dengan perusahaan lain. Juwitasary et.al (2015) menyatakan bahwa peran sistem informasi sangat penting bagi suatu perusahaan untuk memberikan dukungan strategis dalam menjalankan proses bisnis perusahaan.

Setiap kegiatan pengelolaan keuangan, perusahaan saat ini tidak luput dari sistem informasi. Salah satu sistem informasi yang memudahkan perusahaan adalah sistem informasi akuntansi. Sistem informasi akuntansi dapat memudahkan perusahaan dalam menjalankan proses akuntansi. Diantaranya yaitu meng-input transaksi, menyusun laporan keuangan hingga menghasilkan laporan keuangan melalui sistem tersebut. 
Pengolahan data secara manual sudah mulai di tinggalkan dan perusahaan sudah mulai berpindah ke sistem yang terkomputerisasi, hal ini dipicu oleh perkembangan teknologi informasi yang meliputi perkembangan software dan hardware yang semakin maju. Sistem informasi akuntansi merupakan bagian dari sistem yang terkomputerisasi. Sistem informasi akuntansi merupakan salah satu jenis sistem informasi yang diperlukan oleh perusahaan dalam menangani operasionalnya sehari hari untuk menghasilkan informasi seperti informasi pembelian dan penjualan yang di perlukan oleh manajemen perusahaan (Renggaenis, 2012).

Terbantunya perusahaan dalam pengolahan data pembelian dan penjualan produk yang dibantu oleh adanya sistem informasi akuntansi nantinya akan menghasilkan informasi yang tepat waktu dan akurat. Adanya infromasi yang tepat waktu dan juga akurat akan sangat memberikan kesegaran dan membantu manajemen dalam hal yang mendasari pengambilan keputusan dan juga menentukan langkah- langkah yang harus dilakukan untuk kegiatan operasional perusahaan dan juga dalam hal perkembangan perusahaan. Romney dan Steinbart (2015: 5) menyatakan bahwa, pada dasarnya keseluruhan organisasi memerlukan informasi untuk dapat memyususn keputusan yang efektif. Fungsi yang dimiliki oleh sistem informasi akutansi memiliki peranan penting pada sebuah organisasi antara lain adalah menyimpan dan juga menumpulkan data yang berkaitan dengan aktivitas keuangan yang berisikan informasi detail mengenai pembelian dan penjualan. Sementara itu adanya sistem informasi dapat digunakan untuk melakukan transaksi dan memroses data menjadi berbagai informasi yang dapat digunakan untuk transaksi dan memroses data menjadi berbagai informasi yang nantinya diperlukan dalam proses penyususnan keputusan serta melakukan control secara akurat terhadap asset perusahaan.

Pada perusahaan dagang, sistem informasi akuntansi yang meliputi sistem pembelian dan penjualan akan sangat membantu jika di bandingkan dengan pencatatan manual. Pencatatan manual membutuhkan lebih banyak waktu, dimana karyawan harus mengurutkan faktur-faktur yang ada agar transaksi yang telah terjadi dapat diurutkan sesuai dengan waktu transaksi. Dalam pencatatan manual, keamanan data perusahaan akan tidak terjamin dikarenakan dokumen transaksi masih menggunakan kertas yang mudah hilang, rusak ataupun adanya indikasi manipulasi yang dilakukan oleh karyawan, informasi yang disajikan tidak tepat wakt (Daud \& Windana, 2014). Pengelolaan data yang banyak dan kompleks sangat membutuhkan bantuan sistem dalam pengolahannya agar perusahaan dapat memanfaatkannya menjadi lebih baik. Pada sistem yang sudah terkomputerisasi, waktu yang dibutuhkan dalam memperoleh data akan lebih cepat, data yang diterima lebih akurat, sehingga menghasilkan laporan keuangan lebih cepat dari pencatatan dan pelaporan manual serta dapat memberikan waktu yang lebih banyak kepada manajer untuk mengambil keputusan.

Perusahaan Shavira Pancake merupakan objek dari penelitian ini yang berlokasi di Jl. Study Fond No.2A, Kuta Alam, Kota Banda Aceh, Aceh 23121, Indonesia. Perusahaan Shavira Pancake ini bergerak di bidang penjualan makanan seperti pancake durian dan makanan dari olahan durian lainnya yang di produksi di Banda Aceh. Pencatatan aktivitas transaksi selama ini masih menggunakan sistem pencatatan manual, akibatnya sering terjadi keterlambatan dalam rekapitulasi transaksi dan kesulitan dalam mencari informasi transaksi. Nantinya, akan dirancang suatu sistem pembelian dan penjualan untuk memudahkan aktivitas perusahaan ini kedepannya. Output yang akan dihasilkan dari penelitian ini adalah sistem informasi akuntansi pembelian dan penjualan yang dilakukan oleh perusahaan Shavira Pancake. Dari sistem tersebut dapat dihasilkan laporan yang memuat segala transaksi pembelian dan penjualan yang terjadi sealama periode tertentu.

\section{Kajian Pustaka dan Kerangka Pemikiran Sistem}

Romney dan Steinbart (2015: 3) Sistem yaitu serangkaian dua atau lebih elemen yang memiliki keterkaitan dan memiliki interaksi demi tercapainya maksud organisasi, dominannya sistem terbentuk dari subssistem yang lebih rendah dan menyokong sistem yang lebih tinggi. Semua subsistem ini dibuat untuk merealisasikan maksud dari organisasi.

\section{Informasi}

Menurut Adhawiyah, Kumaladewi, \& Utami (2017) Informasi merupakan gabungan dari berbagai pernyataan yang terorganisir dan telah diperbaiki 
supaya mempunyai nilai lebih yang lain selain nilainilai individu. Informasi merupakan data yang telah siap diolah ke dalam sebuah bentuk yang berarti bagi penerimanya yang bermanfaat digunakan bagi pengambilan keputusan saat ini atau masa mendatang Romney dan Steinbart (2015: 4).

\section{Sistem Informasi}

Dalam bukunya, Sutabri (2012: 46) menjelaskan bahwa sistem informasi yaitu suatu sistem dalam organisasi yang mendukung fungsi operasi organisasi, menghubungkan kepentingan pengolahan transaksi harian, dan bersifat manajerial dengan strategis dari organisasi untuk dapat menyajikan laporan yang diperlukan oleh pihak eksternal.

\section{Sistem Informasi Akuntansi}

Sistem informasi akuntansi merupakan sistem yang menghimpun, mencatat, menyimpan dan mengolah data untuk memberikan informasi bagi para manajer. Sistem tersebut terdiri dari manusia, aturan dan instruksi, data, software, infrastruktur teknologo informasi, serta internal control dan security measurement (Romney dan Steinbart, 2015: 10). Kumpulan sumberdaya, seperti manusia dan peralatan, yang diatur untuk mengubah data menjadi informasi merupakan pengertian dari Sistem informasi akuntansi. Informasi ini dihubungkan dengan berbagai jenis pengambilan keputusan (Mujilan, 2012).

\section{Database}

Solichin, (2016: 134) menjelaskan bahwa proses memperoleh informasi dari basis data melalui gabungan informasi yang tersimpan dalam komputer secara sistematis agar dapat di periksa dengan suatu program komputer guna mendapatkan informasi dari basis data tersebut merupakan pengertian dari database.

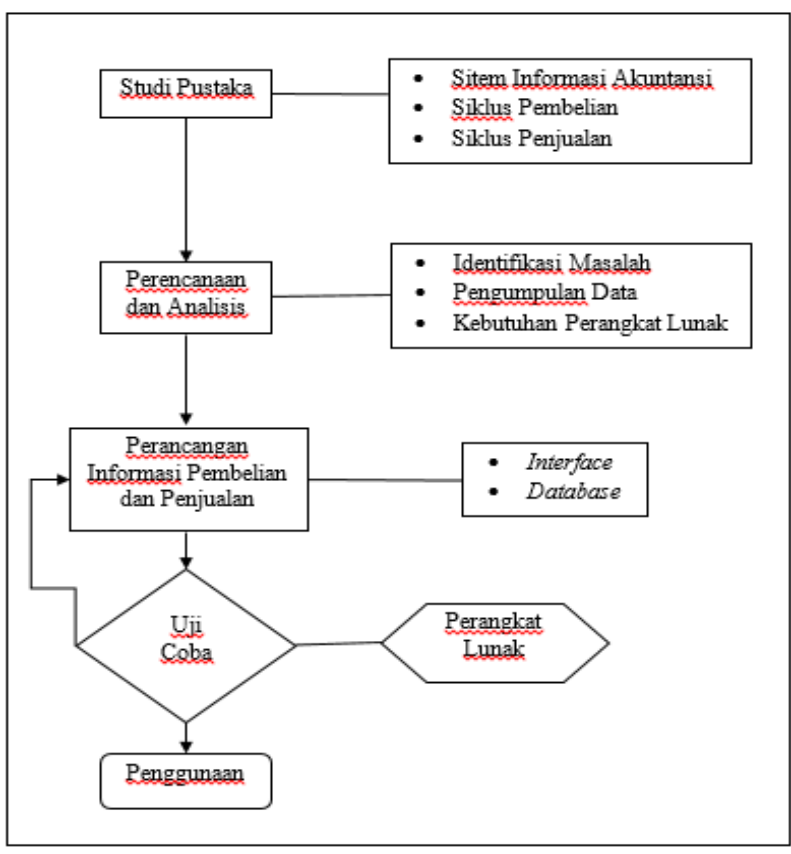

\section{Metode Penelitian}

\section{Desain Penelitian}

Penelitian ini bertujuan untuk menguji hipotesis. Jenis investigasi pada penelitian ini menggunakan jenis penelitian studi koleraional dimana peneliti ingin mengetahui variable yang terkait maka studi korelasional yang akan dilakukan. Situasi penelitian ini adalah tidak diatur. Unit analisis dalam penelitian ini adalah perusahaan yang merupakan Distro Blacksheep dan MenSurfing. dan data yang dikumpulkan yaitu berupa data primer dan data sekunder. Penelitian ini bersifat studi longitudional.

\section{Sumber dan Teknik PengumpulanData}

Sumber data pada penelitian ini adalah data primer dan data sekunder. Data primer berupa wawancara dan observasi dan data sekunder berupa data dokumentasi, seperti faktur penjualan. Teknik pengumpulan data yang digunakan dalam penelitian ini dengan dua cara, yaitu penelitian langsung ke lapangan dan studi kepustakaan.

\section{Proses Rencana Penelitian}

\section{Studi Pustaka}

Proses ini mengumpulkan data pustaka yang berfungsi untuk acuan teori dan berguna untuk menggambarkan sistem informasi persediaan barang. 


\section{Perencanaan dan Analisis}

Pada proses ini peneliti mulai mengembangkan sistem informasi pembelian dan penjualan pada shavira pancake. Proses ini melakukan analisis sehingga menemukan masalah yang terjadi pada perusahaan. Belum adanya sistem pembelian dan penjualan pada distro shavira pancake menjadi salah satu masalah yang terjadi, belum tersedianya basis data pada perusahaan sehingga sulit untuk menyimpan, mengolah, dan menampilkan data secara akurat dan tepat.

\section{Perancangan}

Pada proses ini merancang sebuah konsep diagram alir data dan diagram konteks. Kemudain elamkukan perancangan fisik yang berupa perancangan output. Perancangan ini akan menentukan format dan isi laporan yang dihasilkan.

\section{Pengujian}

Setelah sistem selesai dirancang, maka tahap berikutnya yaitu tahap pengujian. Pada tahap ini berkaitan dengan pemrograman, instalasi, dan rencana pemeliharaan. Pada tahap ini juga dilakukan testing dan training dengan tujuan agar sistem dapat digunakan dengan sebaik-baiknya.

\section{Penggunaan}

Langkah terakhir merupakan tahap dimana sistem yang dirancang telah siap untuk digunakan untuk karyawan.

\section{Hasil danPembahasan Profil Perusahaan}

Shavira Pancake beralamat di Jl. Study Fond No.2A, Kuta Alam, Kota Banda Aceh, Aceh (23121). Perusahaan ini bergerak di bidang penjualan aneka makanan olahan durian yang dikelola oleh bapak Abdul Salam, ST. Shavira Pancake memiliki 5 orang karyawan yang terdiri dari 1 orang di bagian bendahara, 1 orang di bagian gudang, 1 orang di bagian pengemasan/packing dan 2 orang di bagian pengiriman/delivery. Perusahaan ini didirikan pada tahun 2014 dan memiliki pelanggan tetap yang tersebar di sekitar Banda Aceh dan Aceh Besar.

\section{Analisis Sistem dan Prosedur Secara Manual Proses Pembelian Barang}

Setalah melakukan wawancara dan observasi serta mengumpulkan data yang diinginkan dengan pemilik Shavira pancake. Shavira pancake menerapkan tahap untuk membeli barang sebagai berikut:

1. Bagian gudang membuat surat permohonan jika barang tidak tersedia.

2. Pemilik menerima surat permohonan, dan kemudian membuat surat penawaran harga.

3. Surat penawaran harga dikirim ke supplier. Kemudian supplier membuat surat persetujuan harga dan mengirimnya ke pemilik.

4. Berdasarkan surat persetujuan harga tersebut, pemilik membuat daftar pembelian barang.

5. Kemudian pemilik membuat surat pemesanan barang dan dikirim ke supplier.

6. Supplier menerima surat pemesanan barang dari pemilik, kemudian supplier membuat faktur dan dikirim ke Bendahara.

7. Bendahara menerima faktur dan barang pesanan dari supplier dan mengecek apakah barang sesuai. Kemudian barang dikirim ke bagian gudang.

8. Bagian gudang menerima barang dan mencatat barang masuk dan mencatat barang sesuai dengan surat pemesanan barang. Kemudian membuat laporan penerimaan barang dan dikirim ke bendahara.

9. Bendahara menerima surat pemesanan barang, faktur, dan laporan penerimaan barang. Berdasarkan hal tersebut bendahara melakukan pembayaran kepada supplier.

\section{Proses Penjualan Barang}

Setalah melakukan wawancara dan observasi serta mengumpulkan data yang diinginkan, Shavira pancake menerapkan tahap untuk membeli barang sebagai berikut:

1. Costumer membuat daftar pesanan yang akan diterima oleh pemilik.

2. Pemilik menerima daftar pesanan dan membuat faktur lunas dan mengirim ke costumer.

3. Costumer menerima faktur dan melakukan pembayaran.

4. Setelah menerima pembayaran pemilik membuat tanda terima dan mengirimkan barang yang telah di pesan. 
5. Tanda terima diberikan ke bendahara.

6. Setelah barang dikirim, bendahara membuat laporan dan menyerahkan ke pemilik.

\section{DiagramKonteks}

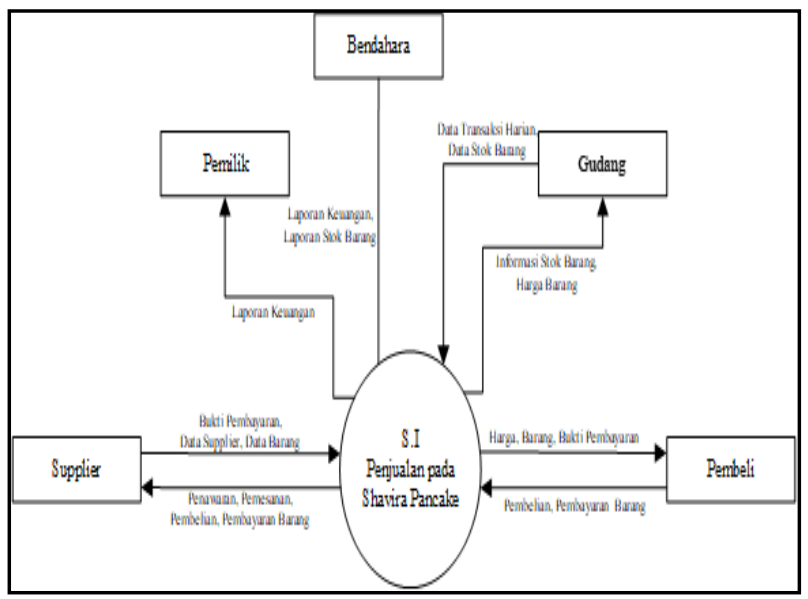

\section{Diagram Arus Data}

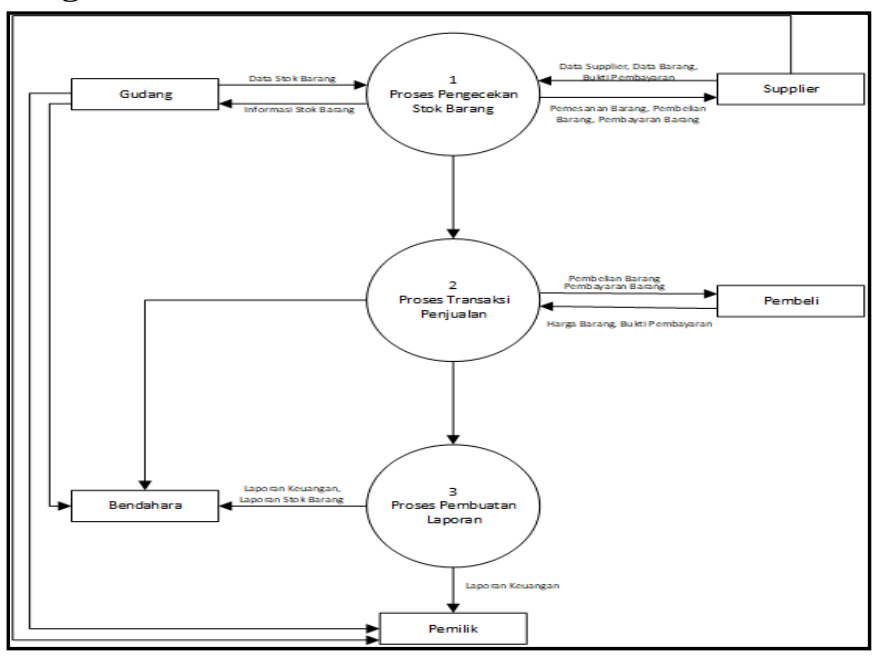

Evaluasi Sistem Berjalan

\begin{tabular}{|c|c|c|}
\hline No & Permasalahan & Solusi/Rencana \\
\hline 1 & $\begin{array}{l}\text { Pencatatan transaksi masih } \\
\text { menggunakan pencatatan } \\
\text { manual }\end{array}$ & $\begin{array}{l}\text { Dengan dibuatnya sistem informasi. } \\
\text { proses pencatatan dapat dilakukan } \\
\text { langsung setiap ada transaksi secara } \\
\text { komputerisasi }\end{array}$ \\
\hline 2 & $\begin{array}{l}\text { Keamanan data masih belum } \\
\text { terjamin }\end{array}$ & $\begin{array}{l}\text { Dengan adanya sistem informasi } \\
\text { menjamin keamanan data yang ada } \\
\text { dengan menggunakan metode } \\
\text { sistem Log In }\end{array}$ \\
\hline 3 & $\begin{array}{l}\text { Laporan Pembelian dan } \\
\text { Penjualan masih tidak akurat }\end{array}$ & $\begin{array}{l}\text { Dengan diterapkannya sistem } \\
\text { informasi laporan pembelian dan } \\
\text { penjualan dapat dilihat secara akurat }\end{array}$ \\
\hline
\end{tabular}

\section{Analisis Kebutuhan Sistem Informasi Usulan}

Pada sebuah perusahaan sistem informasi merupakan hal yang cukup krusial. Suatu sistem memiliki keunggulan yang dapat dilihat dari informasi yang yang dihasilkan. Dari hasil analisis sistem yang sedang berjalan dapat dilihat permasalahan apa saja yang terjadi pada perudahaan Shavira Pancake, Maka perlu dihasilkan suatu solusi untuk permasalahan yang ada dengan merancang sistem informasi pembelian dan penjulan pada perusahaan Shavira pancake. Sistem informasi pembelian dan penjualan nantinya akan mendukung kegiatan bisnis di Shavira seperti pencatatan transaksi dan menghasilkan laporan pembelian dan penjualan baik dalam softcopy ataupun hardcopy.

\section{Analisis Data}

Masalah yang ada dalam perusahaan Shavira Pancake ini salah satunya adalah masih menggunakan pencatatan manual. Saat ini, Pencatatan dan penyimpanan data yang dilakukan masih menggunakan buku/kertas yang memiliki resiko rusak atau hilang. ketika pihak manajemen perusahaan ingin memeriksa pendapatan melalui laporan penjualan sering tidak sesuai dengan pencatatan harian, hal ini menimbullan masalah ketika karyawan memeriksa data satu persatu yang akan memakan waktu cukup lama.

Adanya sistem pembelian dan penjuaalan akan memudahkan perusahaan dalam proses pencatatan transaksi dan menghasilkan laporan pembelian dan penjualan. Setiap transaksi yang diinput akan langsung mempengaruhi dan mengkalkulasikan seluruh transaksi di Shavira Pancake. Oleh karena itu Shavira Pancake membutuhkan suatu sistem yang dapat digunakan dengan mudah.

\section{Analisis Penyimpanan Data}

Penyimpanan data transaksi pada perusahaan Shavira Pancake Banda Aceh yang saat ini digunakan adalah buku ataupun kertas yang dikumpul dan kemudian diarsipkan. Data-data transaksi ini akan sulit untuk dicari dan membutuhkan waktu yanglama ketika diperlukan, dikarenakan banyaknya lembaran kertas dan penyimpanannya tidak sesuai no transaksi ataupun tanggal transaksi. Data yang disimpan juga beresiko hilang atau rusak dikarenakan data tersebut tidak diberikan pengamanan.

\section{Analisis Kebutuhan Sistem yang Diusulkan}

Dari permasalahan diatas dapat disimpulkan bahwa perusahaan Shavira Pancake Banda Aeh membutukan suatu sistem informasi pembelian dan penjualan secara komputerisas. Sistem ini nantinya 
diharapkan dapan dioperasikan dengan mudah oleh karyawan untuk mencatat transaksi dan dapat meminimalisir kesahalan dalam pencatatan transaksi. Sistem informasi tersebut mliputi hal-hal berikut:

1. Tingkat keamanan dan kemudahan akses yang lebih terjamin dari sebelumnya sehingga pihak yang terkait mampu mengakses informasi dengan cepat.

2. Sistem yang dapat melakukan penghitungan otomatis terhadap transaksi agar menjadi laporan pembelian dan penjualan.

3. Sistem yang dapat menampilkan dengan jelas proses pencatatan transaksi hingga menghasilkan laporan pembelian dan penjualan.

4. Sistem yang dapat menghasilkan laporan pembelian dan penjualan dari seluruh transaksi yang terjadi pada perusahaan.

\section{Perancangan Sistem}

Perancangan system merupakan sebuah proses pembangunan sistem baru dari hasil analisis sistem. Perancangan sistem dapat dilihat dari unsur-unsur yang dibutuhkan untuk meningkatkan kinerja perusahaan. Perancangan sistem meliputi input, process dan juga output dari yang diusulkan.

\section{Diagram Konteks yang Diusulkan}

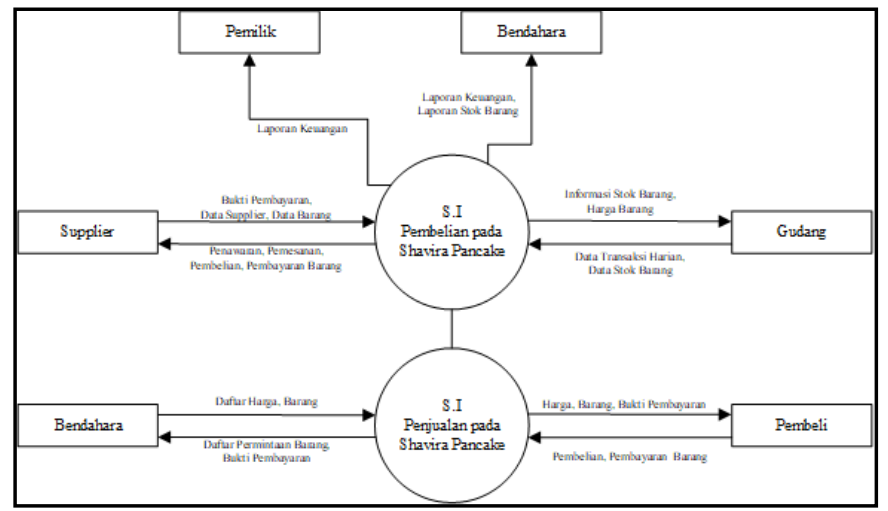

Diagram Arus Data yang Diusulkan

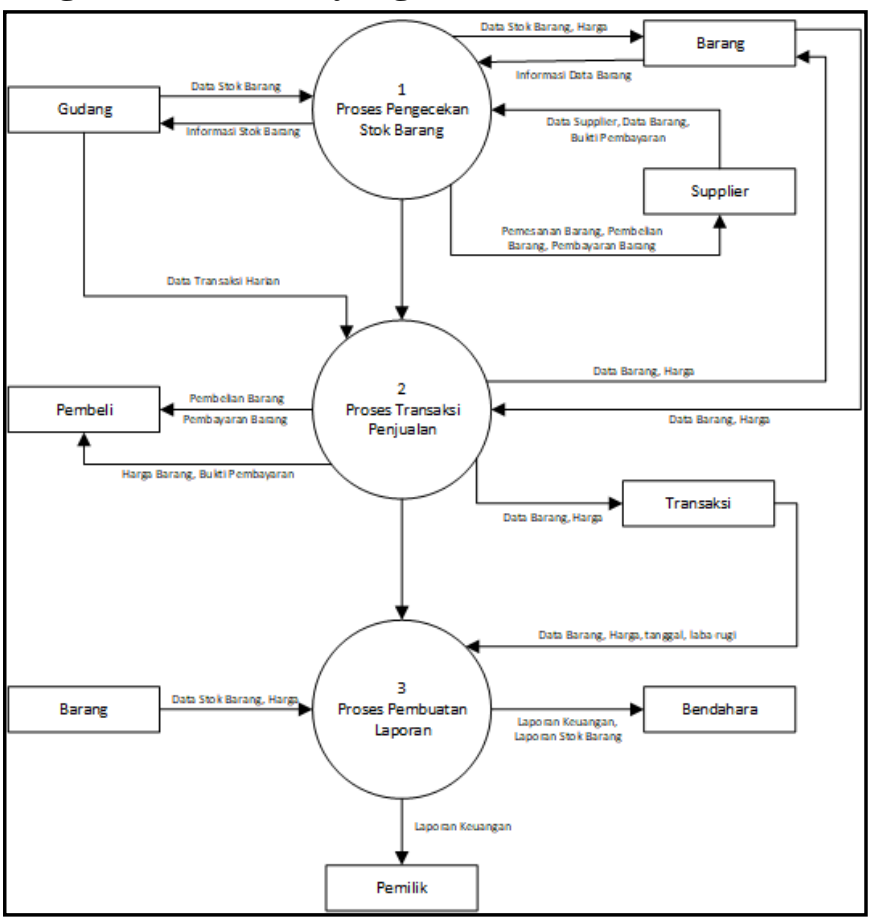

\section{Penggunaan Sistem}

Dari hasil pengujian sistem yang telah dilakukan, dapat disimpulkan bahwa sistem informasi pembelian dan penjualan ini dapat berfungsi sesuai dengan harapan di perusahaan Shavira Pancake Banda Aceh. Sistem ini akan digunakan oleh karyawan yang terlibat langsung dalam bagian bendahara gudang dan kasir. Karyawan yang bertanggung jawab pada bagianbagian tersebut akan diberikan kode akses/password dengan tujuan mengantisipasi terjadinya kehilangan ataupun kerusanakan data dan karyawan tidak diizinkan untuk memberikan password tersebut bagi yang tidak berkepentingan.

Dari hasil pengujian sistem yang telah dilakukan, dapat disimpulkan bahwa sistem informasi pembelian dan penjualan ini dapat berfungsi sesuai dengan harapan di perusahaan Shavira Pancake Banda Aceh. Sistem ini akan digunakan oleh karyawan yang terlibat langsung dalam bagian bendahara gudang dan kasir. Karyawan yang bertanggung jawab pada bagianbagian tersebut akan diberikan kode akses/password dengan tujuan mengantisipasi terjadinya kehilangan ataupun kerusanakan data dan karyawan tidak diizinkan untuk memberikan password tersebut bagi yang tidak berkepentingan. 


\section{Kesimpulan}

Setelah melakukan penelitian dan menerapkan sistem pada Perusahaan Shavira Pancake Banda Aceh, kesimpulan yang dapat diambil adalah:

1. Merancang sistem informasi pelaporan keuangan Perusahaan Shavira Pancake menghasilkan sistem informasi pembelian dan penjualan yang lebih baik.

2. Perancangan sistem informasi pembelian dan penjualan pada Perusahaan Shavira Pancake menghasilkan dua data item, yaitu data input yang merupakan data masukan berupa data transaksi dari transaksi perusahaan dan data output berupa laporan pembelian dan penjualan.

3. Database yang saling berhubungan menghasilkan sistem yang mudah dioperasikan ketika memasikan data melalui form.

4. Penyimpanan data lebih efektif dan efisien karena satu file database dapat menyimpan banyak informasi

5. Sistem informasi Pembelian dan penjualan yang dirancang, membuat perusahaan lebih mudah mencari data transaksi dan tidak membutuhkan waktu yang lama

\section{Saran}

1. Sebaiknya perusahaan melakukan pengawasan secara berkala pada penggunaan perangkat keras dan perangkat lunak yang digunakan sehingga meminimalisir terhambatnya kegiatan bisnis perusahaan

2. Melakukan training terhadap karyawan yang akan mengoperasikan sistem agar sistem dapat berjalan dengan efektif dan efisien

\section{Daftar Pustaka}

Adhawiyah, Y., Kumaladewi, N., \& Utami, M. C. (2017). Rancang Bangun Sistem Informasi Penilaian Kinerja Pegawai Menggunakan Metode Psycological Appraisal, 10(2), 119-126. Bastian, A., Prasetyo, T. F., \& Kurniati, N. (2017). Rancanga Bangun Sistem Informasi Manajemen Peternak Ayam pada Koperasi Sinar Mulya Menggunakan Microsoft Visual Basic 2010. Net. Studia Informatika: Jurnal Sistem Informasi, 10(2), 135-143.

Daud, R., \& Windana, V. M. (2014). Pengembangan Sistem Informasi Akuntansi Penjualan Dan
Penerimaan Kas Berbasis Komputer Pada Perusahaan Kecil (Studi Kasus Pada Pt. Trust Technology). Jurnal Manajemen Dan Bisnis Sriwijaya, 12(1), 17-28. Retrieved from http://eprints.unsri.ac.id/3771/

Juwitasary, H., Martani, M., Nata, A., \& Putra, G. (2015). Pembelian Dan Persediaan Pada Pt . Xyz. Analisis Sistem Informasi, 6(1), 96-108. Retrieved from http://journal.binus.ac.id/index.php/comtech/arti cle/view/2294

Mujilan, A. (2012). Sistem Informasi Akuntansi Teori dan Wawasan. Madiun: Prodi Akuntansi Universitas Widya Mandala.

Renggaenis, P. A. P. (2012). Analisis dan Perancangan Sistem Informasi Akuntansi Persediaan Barang Dagang Pada OASSURE - SISKEM Aneka Indonesia. Repository Universitas Gunadarma, 91(2008), 399-404.

Romney, M. B., \& Steinbart, P. J. (2015). Sistem Informasi Akuntansi (13th ed.). Jakarta: Salemba Empat.

Solichin, A. (2016). Pemrograman Web dengan PHP dan MySQL. Jakarta: Budi Luhur.

Sutabri, T. (2012). Konsep Sistem Informasi. ANDI. 